\title{
Special issue on freshwater ascomycetes and other aquatic fungi
}

\author{
Christiane Baschien ${ }^{1} \cdot$ Kevin D. Hyde ${ }^{2}$ \\ Published online: 18 April 2018 \\ (C) German Mycological Society and Springer-Verlag GmbH Germany, part of Springer Nature 2018
}

This special issue on aquatic fungi is dedicated to Carol Shearer, and the late John Webster and Terrence Ingold, who initiated research on the fungi in these habitats. This special issue brings together ten papers on aquatic fungi, which are those taxa that grow on submerged substrates in aquatic bodies, such as ponds, streams, lakes, and rivers, as well as saline habitats. Aquatic fungi are both interesting and important and can be split into several ecological groups: the lignicolous freshwater fungi that generally grow on submerged wood, the Ingoldian or leaf-inhabiting fungi which grow on submerged leaves in freshwater, and those fungi that grow on substrates in saline habitats. Aquatic fungi are important in the decay of plant material in streams and thus nutrient cycling. Aquatic fungi in particular have the potential to monitor pollution and may be seriously affected with the effects of climate change. Therefore, their study has become important. Freshwater bodies are also one of the few habitats where fungi can be found all year round-because as long as the stream has water, it will have freshwater fungi. The fungi range from solely aquatic species to those that occur in terrestrial habitats and support a huge diversity, particularly across the ascomycetes. Thus, much novelty is yet to be found.

When we envisaged this special issue, we had hoped for papers from around the world. Previous hotspots for research on aquatic fungi were in the USA (Illinois, Shearer and coworkers), Australia (north Queensland, Hyde and co-workers), Canada (Bärlocher and co-workers), the Czech Republic (Marvanová and co-workers), mainland China (Yunnan Province, Hyde and co-workers), Hong Kong (Hyde and co-

Section Editor: Kevin Hyde and Christiane Baschien

This article is part of the "Special Issue on Freshwater Ascomycota."

Christiane Baschien

chb14@dsmz.de

1 Leibniz Institute DSMZ - German Collection of Microorganisms and Cell Cultures, Inhoffenstraße 7B, 38124 Braunschweig, Germany

2 Centre of Excellence in Fungal Research, Mae Fah Luang University, Chiang Rai, Thailand workers), Spain, (Descals and co-workers), Thailand (Jones and co-workers), and the UK (Ingold, Webster and coworkers). More recently, several groups studying freshwater fungi have started research in China, because of the importance of water and the perceived drying out of water bodies which is expected with climate change. Eventually, we only received papers from the groups in the Asian region and from Iran which are presently most active. This special issue of Mycological Progress on aquatic fungi therefore provides ten papers on the taxonomy and phylogeny of freshwater fungi, mostly from the Asian region.

Papers can be categorized into two main themes. Most papers deal with the taxonomy and phylogeny of freshwater fungi, including novel species in the families Pleurotheciaceae (Luo et al. 2018), Torulaceae (Su et al. 2018), and Jahnula dianchia sp. nov. (Huang et al. 2018) from Yunnan Province in China. Two new helicosporous hyphomycetes from Taiwan are introduced (Kuo and Goh 2018). The new chaetothyrialean taxa, Aculeata aquatica gen. et sp. nov., Minimelanolocus thailandensis sp. nov., and Thysanorea aquatica sp. nov. (Herpotrichiellaceae), are introduced from northern Thailand (Wanasinghe et al. 2018). Neohelicosporium gen. nov. and five new species of helicosporous hyphomycetes are introduced in Tubeufiales (Yang et al. 2017), Pseudostanjehughesia aquitropica gen. et sp. nov., and Sporidesmium sensu lato species (Tian et al. 2016), and novel palm taxa within Pleosporales ( $\mathrm{Lu}$ et al. 2017) are introduced from China and northern Thailand. Two novel species of bambusicolous fungi in the genus Kamalomyces, were described from northern Thailand (Phookamsak et al. 2017). One paper deals with Neocamarosporium species from saline lakes in Iran (Papizadeh et al. 2017).

\section{References}

Huang S-K, Maharachchikumbura SSN, Jeewon R, Jayarama Bhat D, Chomnunti P, Hyde KD, Lumyong S (2018) Morphological and molecular taxonomy of Jahnula dianchia sp. nov. (Jahnulales) from 
submerged wood in Dianchi Lake, Yunnan. Mycol Prog. https://doi. org/10.1007/s11557-018-1390-9

Kuo C-H, Goh T-K (2018) Two new species of helicosporous hyphomycetes from Taiwan. Mycol Prog. https://doi.org/10.1007/s11557$018-1384-7$

Lu Y-Z, Boonmee S, Liu J-K, Hyde KD, McKenzie EHC, Eungwanichayapant PD, Kang J-C (2018) Multi-gene phylogenetic analyses reveals Neohelicosporium gen. nov. and five new species of helicosporous hyphomycetes from aquatic habitats. Mycol Prog. https://doi.org/10.1007/s11557-017-1366-1

Luo Z-L, Hyde KD, Bhat DJ, Jeewon R, Maharachchikumbura SSN, Bao D-F, Li W-L, Su X-J, Yang X-Y, Su H-Y (2018) Morphological and molecular taxonomy of novel species Pleurotheciaceae from freshwater habitats in Yunnan, China. Mycol Prog. https://doi.org/10. 1007/s11557-018-1377-6

Papizadeh M, Wijayawardene NN, Amoozegar MA, Saba F, Fazeli SAS, Hyde KD (2018) Neocamarosporium jorjanensis, N. persepolisi and $N$. solicola spp. nov. (Pleosporaceae, Pleosporales) isolated from saline lakes of Iran indicate the possible halotolerant nature for the genus. Mycol Prog. https://doi.org/10.1007/s11557-017$1341-\mathrm{x}$

Phookamsak R, Lu Y-Z, Hyde KD, Jeewon R, Li J, Doilom M, Boonmee S, Promputtha I (2017) Phylogenetic characterization of two novel
Kamalomyces species in Tubeufiaceae (Tubeufiales). Mycol Prog. https://doi.org/10.1007/s11557-017-1365-2

Su X-J, Luo Z-L, Jeewon R, Bhat DJ, Bao D-F, Wen-Li LI, Hao Y-E, Su H-Y, Hyde KD (2018) Morphology and multigene phylogeny reveal new genus and species of Torulaceae from freshwater habitats in northwestern Yunnan, China. Mycol Prog. https://doi.org/10.1007/ s11557-018-1388-3

Tian Q, Doilom M, Luo Z-L, Chomnunti P, Bhat JD, Xu J-C, Hyde KD (2018) Introducing Aculeata aquatica gen. et sp. nov., Minimelanolocus thailandensis sp. nov. and Thysanorea aquatica sp. nov. (Herpotrichiellaceae, Chaetothyriales) from freshwater in northern Thailand. Mycol Prog. https://doi.org/10.1007/s11557018-1389-2

Wanasinghe DN, Jeewon R, Gareth Jones EB, Boonmee S, Kaewchai S, Manawasinghe IS, Lumyong S, Hyde KD (2018) Novel palmicolous taxa within Pleosporales: multigene phylogeny and taxonomic circumscription. Mycol Prog. https://doi.org/10.1007/ s11557-018-1379-4

Yang J, Maharachchikumbura SSN, Liu J-K, Hyde KD, Gareth Jones EB, Al-Sadi AM, Liu Z-Y (2018) Pseudostanjehughesia aquitropica gen. et sp. nov. and Sporidesmium sensu lato species from freshwater habitats. Mycol Prog. https://doi.org/10. 1007/s11557-017-1339-4 